\title{
Evaluation of quality of life of patients with pollen allergy before and after sublingual immunotherapy course
}

\author{
S. 0. Zubchenko ${ }^{1}$, S. R. Maruniak ${ }^{2}$ \\ ${ }^{1}$ Danylo Halytsky Lviv National Medical University, Ukraine, ${ }^{2}$ Shupyk National Medical Academy of Post-Graduate Education, Kyiv, Ukraine
}

Key words: pollen allergy, allergic rhinitis, quality of life, sublingual allergy immunotherapy.

Pathologia 2018; 15 (2), 210-214 DOI: 10.14739/2310-1237. 2018.2.141395

E-mail: svitlana_zu@meta.ua

In Ukraine, there are over 1.5 thousand types of weeds, which may provoke the development of allergic reactions. Based on our observation, most commonly sensitization to Artemisia and less often to Ambrosia is recorded in patients of Lviv region. The presence of clinical symptoms significantly deteriorates life quality of patients with pollen allergy and requires conduction of proper allergy immunotherapy.

Aim. To analyze QOL of patients with allergy to weed pollen before and after conduction of sublingual immunotherapy based on a specialized questionnaire MiniRQLQ.

Materials and methods. Totally, 485 individuals, $24.0 \pm 4.5$ years old were examined. Clinical diagnosis of AR was made according to ARIA criteria (2014). SPT to standard inhaled allergens (Diater-Laboratories, Spain), total serum and specific immunoglobulins IgE, IFA, type-specific components of allergens, immunofluorescent method immunoCAP ("Phadia AB", Sweden) were determined. Analysis of life quality was performed based on questionnaire MiniMRQLQ.

Results. Among patients of Lviv region with pollen allergy, the most commonly detected positive SPT were to Artemisia - in $62.3 \%$, less to Ambrosia $-13.9 \%$ of individuals, combined sensitization $-23.8 \%$ of patients. Among them, genuine allergy to Artemisia was confirmed in $88.1 \%$, to Ambrosia - $88.2 \%$ of individuals, co-sensitization - in 21 patients. According to the results of molecular investigations, SLIT was performed for $69.6 \%$ of patients (the $1^{\text {st }}$ group), $30.4 \%$ of individuals were treated symptomatically (the $2^{\text {nd }}$ group). Based on questionnaire MiniRQLQ, it was revealed that $Q O L$ indices in patients with pollen allergy, who underwent SLIT, were reliably lower after the first and the second years of treatment compared to the indices before SLIT. Reliable changes were not detected in patients of the second group.

Conclusions. Improvement of QOL indices after a course of SLIT indicated the high efficacy of this treatment method in patients with pollen allergy.

Ключові слова: пилкова алергія, алергічний риніт, якість життя, сублінгвальна алергоімунотерапія.

Патологія. - 2018. -

T. 15, № 2(43). -

C. 210-214

\section{Оцінювання якості життя пацієнтів із пилковою алергією до та після курсу сублінгвальної імунотерапії}

\section{С. О. Зубченко, С. Р. Маруняк}

В Україні налічується понад 1,5 тис. видів бур'янистих рослин, які можуть призвести до розвитку алергічних реакцій. За нашими спостереженнями, в пацієнтів Львівської області найчастіше виявляється сенсибілізація до полину та меншою мірою до амброзії. Наявність клінічної симптоматики суттєво погіршує якість життя пацієнтів із пилковою алергією та потребує проведення адекватної алергоімунотерапії.

Мета роботи - проаналізувати QOL пацієнтів з алергією до пилку бур'янів до та після проведення сублінгвальної імунотерапії на підставі спеціалізованої анкети MiniRQLQ.

Матеріали та методи. Обстежили 485 осіб віком 24,0 4 4,5 року. Клінічний діагноз АР визначений відповідно до критеріїв ARIA (2014). Визначали SPT до стандартних інгаляційних алергенів (Diater-Laboratories, І Іпанія), загальний сироватковий та специфічні імуноглобуліни IgE, IФА, видоспецифічні компоненти алергенів, використали імунофлуоресцентний метод ImmunoCAP («Phadia AB», Швеція). Аналіз якості життя виконали за анкетою MiniMRQLQ.

Результати. Серед пацієнтів Львівської області з пилковою алергією найчастіше визначені позитивні SPT до полину - у 62,3 \%, менше до амброзії - 13,9 \%, комбінована сенсибілізація -23,8 \% осіб. 3 них підтверджена істинна алергія до полину у 88,1 \%, до амброзії - у 88,2 \% осіб, ко-сенсибілізація у 21 особи. Відповідно до результатів молекулярних досліджень, SLIT проводили 69,6 \% пацієнтам (1 група), 30,4 \% осіб отримували симптоматичну терапію (2 група). На підставі опитувальника MiniRQLQ визначили, що показники QOL у пацієнтів із пилковою алергією, що отримали SLIT були вірогідно нижчими після першого та другого років лікування порівняно з показниками до SLIT. У пацієнтів 2 групи вірогідних змін не виявили.

Висновки. Компонентні дослідження дають можливість діагностувати наявність істинної алергії до пилку бур'янів і на їх підставі призначити есрективну AIT. У нашому дослідженні істинна алергія підтверджена у 88,1% (полин) та у 88,2 \% (амброзія) пацієнтів. Поліпшення показників QOL після курсу SLIT вказувало на високу ефективність цього методу терапії в пацієнтів із пилковою алергією.
Ключевые слова: пыльцевая аммергия, аммергический ринит, качество жизни, сублингвальная аммергоиммунотерапия.

\section{Оценка качества жизни пациентов с пыльцевой амергией до и после курса сублингвальной иммунотерапии}

\section{С. А. Зубченко, С. Р. Маруняк}

В Украине насчитывается более 1,5 тыс. видов сорных растений, которые воздействуют развитию аллергических реакций. По нашим наблюдениям, у пациентов Львовской области чаще всего встречается сенсибилизация к полыни 
и реже к амброзии. Наличие клинической симптоматики значительно ухудшает качество жизни пациентов с аллергией на пыльцу и требует проведения адекватной аллергоиммунотерапии.

Цель работы - проанализировать QOL пациентов с аллергией к пыльце сорняков до и после проведения сублингвальной иммунотерапии на основании специализированной анкеты MiniRQLQ.

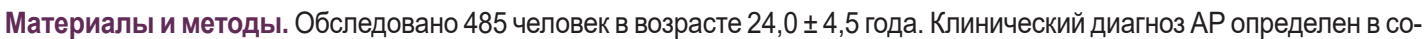
ответствии с критериями ARIA (2014). Определяли SPT к стандартным ингаляционным аллергенам (Diater-Laboratories, Испания), общий сывороточный и специфические иммуноглобулины $\operatorname{lgE}$, ИФА, использовали видоспецифические компоненты аллергенов, иммунофлуоресцентный метод ImmunoCAP («Phadia AB», Швеция). Анализ качества жизни проводили по анкете MiniMRQLQ.

Результаты. Среди пациентов Львовской области с аллергией на пыльцу чаще выявлены положительные SPT к полыни - в 62,3 \%, реже к амброзии - 13,9 \%, комбинированная сенсибилизация - 23,8 \% лиц. Из них подтверждена истинная аллергия к полыни в 88,1\%, к амброзии - 88,2 \% лиц, ко-сенсибилизация у 21 пациента. Согласно результатам молекулярных исследований, SLIT проводили 69,6 \% пациентам (1 группа), 30,4 \% получали симптоматическую терапию (2 группа). На основании опросника MiniRQLQ определили, что показатели QOL у пациентов с пыльцевой аллергией, которые проходили SLIT, были достоверно ниже после первого и второго годов лечения по сравнению с показателями до SLIT. У пациентов 2 группы достоверных изменений не выявлено.

Выводы. Компонентные исследования дают возможность диагностировать наличие истинной аллергии к пыльце сорняков и на их основании назначить эффективную АИТ. В нашем исследовании истинная аллергия подтверждена у 88,1 \% (полынь) и 88,2 \% (амброзия) пациентов. Улучшение показателей QOL после курса SLIT указывало на высокую эфффективность данного метода терапии у пациентов с пыльцевой аллергией.

\section{Introduction}

Allergy to weed pollen is quite common worldwide including Ukraine. It is known that over 1.5 thousand types of weed plants grow on the territory of our country, which may provoke the development of allergic reactions. The most common clinically significant weed allergens worldwide are present in the pollen of Artemisia, Ambrosia, orach, plantain, and saltwort [1].

The main clinical manifestations of allergy to weed pollen are allergic rhinitis/rhinosinusitis (AR), conjunctivitis and bronchial asthma (BA). Thus, symptoms vary in patients, and in most cases, there are rhinorrhea, sneezing, itching, conjunctivitis, cough, breathlessness, etc [2]. This condition is considerably deteriorated due to a person's quality of life (QOL) and often results in temporary disability.

The basic method of treatment of sensitized patients with clinical manifestations of allergy to weed pollen is allergy immunotherapy (AIT). Currently, there are many evidence investigations concerning AIT efficacy in patients with pollen allergy. However, the majority of them focus only on the analysis of AIT influence on reduction of clinical manifestations or comparison of efficacy of different AIT methods (sublingual, subcutaneous, etc.) [3].

Nowadays there is a need in paying more attention to investigations concerning estimation of $\mathrm{QOL}$ of patients with allergic pathology, especially after treatment. Undoubtedly, implementation of the notion "QOL" into somatic medicine practice can be considered a significant progress compared with the traditional tendency to focusing solely on the disease and its symptoms. Besides, medical aspects of QOL define not only patients' health condition, but also the condition of social, material, intellectual and mental well-being, etc. [4].

\section{The aim}

The aim of our research was to analyze QOL of patients with allergy to weed pollen before and after conduction of sublingual immunotherapy (SLIT) based on specialized questionnaire MiniRQLQ.

\section{Materials and methods}

This cohort prospective investigation was performed at the department of clinical immunology and allergology of Danylo Halytsky Lviv National Medical University and in Lviv regional medical center of clinical immunology and allergology, Ukraine, with the participation of Medical Intern of Shupyk National Medical Academy of Post-Graduate Education. The research had been lasting for three years starting from March 2014.

In the given period, 485 individuals aged from 3 to 67 years were examined (average age $24.0 \pm 4.5$ ), 291 males $(60.0 \%), 194$ females $(40.0 \%)$. The criteria for inclusion were age from 18 years, clinical diagnosis of AR made according to ARIA criteria (2014), and sensitization to at least one weed extract (Ambrosia and/or Artemisia (according to the data of skin prick tests (SPT). The criteria for exclusion were combination of $A R$ and $B A$, age under 18 , adults who had received AIT previously, the presence of mental, lingual and cognitive disorders. Thus, 122 individuals were selected for further investigation.

At the time of selection, patients' allergy symptoms were evaluated and analysis of case history was done. Total laboratory, instrumental and specific immunological investigations were performed, in particular, SPT to standard inhaled allergens (Diater-Laboratories, Spain): Der. pteronyssinus, Der. farina, a mixture of spring trees, a mixture of grass, Artemisia, Ambrosia, Alternaria alternata, cats and dogs [5]. Determination of total serum and specific immunoglobulins lgE (slgE) class was performed with enzyme immunoassay using test-systems Euroimmun. For detection of the levels of specific IgE class antibodies, ImmunoCAP (Thermo Scientific, Uppsala, Sweden). Three marker allergens of genuine sensitization to pollen of Artemisia (nArt $\vee 1$, rArt $\vee 3$ ) and Ambrosia (rAmb a 1) were determined. Levels of slgE $>0.35 \mathrm{KU} / \mathrm{l}$
Патология. - 2018. T. 15, № 2(43). C. $210-214$ 
were considered positive. Totally, 71 individuals with AR received a two-year course of immunotherapy using sublingual allergens of Artemisia and Ambrosia Diater, Spain. Patients of the second group received symptomatic treatment in the form of non-sedative antihistamines (tablets, eye drops, nasal sprays etc.). Monitoring of QOL was conducted before therapy (SLIT or symptomatic) and after the first and the second years of treatment, during visits for consultations. More data are given in Table 1. The study was conducted in accordance with the seventh revision of the principles of the Declaration of Helsinki on Human Rights (2013). Information consent was received from the patients.

Table 1. The characteristics of the investigated groups of patients

\begin{tabular}{|c|c|}
\hline Indicator & Results \\
\hline Number of patients, $n$ & 122 \\
\hline \multicolumn{2}{|l|}{ Sex, $n(\%)$} \\
\hline Male & $74(60.7 \%)$ \\
\hline Female & $48(39.3 \%)$ \\
\hline Age $(M \pm m)$, year & $29.30 \pm 2.95$ \\
\hline \multicolumn{2}{|l|}{ Clinical symptoms, $\mathrm{n}(\%)$} \\
\hline Rhinitis & $118(96.7 \%)$ \\
\hline Rhinoconjunctivitis & $63(51.6 \%)$ \\
\hline Allergic asthma & $9(7.4 \%)$ \\
\hline Wheezing & $8(6.6 \%)$ \\
\hline Upper palate itching & $13(10.7 \%)$ \\
\hline Cough & $70(57.4 \%)$ \\
\hline Sneezing & $100(81.9 \%)$ \\
\hline \multicolumn{2}{|l|}{ The results of SPT (average diameter of papule, $\mathrm{mm}$ ): } \\
\hline Artemisia & $4.7 \pm 2.7$ \\
\hline Ambrosia & $11.2 \pm 3.4$ \\
\hline $\begin{array}{l}\text { Number of patients with polyvalent sensitization, } n(\%)- \\
\text { according to the data of SPT }\end{array}$ & $112(91.8 \%)$ \\
\hline Monosensitized (\%) & $10(8.2 \%)$ \\
\hline Ambrosia & $3(2.5 \%)$ \\
\hline Artemisia & $7(5.7 \%)$ \\
\hline
\end{tabular}

\section{Analysis Q0L}

Analysis of life quality was conducted based on validated questionnaire MiniMRQLQ. The MiniRQLQ has 14 items in five domains (activity limitation [ $n=3]$, practical problems [ $n=2$ ], nose symptoms [ $n=3$ ], eye symptoms $[n=3]$ and other symptoms [ $n=3])$. The questionnaire is in a self-administered format and is completed by patients without an interviewer's assistance. Patients are asked to consider how they have been and to respond to each question on a seven-point scale $(0=$ not troubled, 1 = hardly troubled at all, 2 = somewhat troubled, $3=$ moderately troubled, $4=$ quite a bit troubled, $5=$ very troubled, $6=$ extremely troubled).

The statistical processing of the obtained results was made using freeware Libre Office calc 6.1 for Ubuntu 16.04 LTS. We applied the Wilcoxon (sum of the signed ranks) criterion to define the probability of changes in patients' life quality after the $1^{\text {st }}$ and the $2^{\text {nd }}$ years of treatment inside the groups. We applied the Mann-Whitney U-test to define the probability of changes in patients' life quality after the $2^{\text {nd }}$ year of treatment between the $1^{\text {st }}$ and the $2^{\text {nd }}$ groups.

\section{Results}

Among 472 patients with pollen allergy, positive SPT to weeds were detected in $122(25.8 \%)$ individuals. Among them, monosensitization to Artemisia was in 7 (5.7 \%) persons, monosensitization to Ambrosia - in $3(2.5 \%)$ individuals. As predicted, polysensitization was observed in $112(91.8 \%)$ patients. Among polysensitized individuals, positive SPT to Artemisia were detected in 69 (61.6\%), to Ambrosia - in 14 (12.5\%) patients, combined sensitization to two types of weeds was found in 29 (25.9\%) patients. Thus, sensitization to Artemisia was observed in $76(62.3 \%)$ individuals, to Ambrosia - in 17 (13.9\%), co-sensitization - in 29 (23.8 \%) persons.

Therefore, to detect genuine sensitization to Artemisia and Ambrosia for selection of a correct treatment tactics, we offered patients with mono-and polysensitization to perform allergen-component analysis. Among 76 patients with positive SPT to Artemisia, the presence of genuine

Table 2. The estimation of results of patients' life quality with SLIT (group 1) and symptomatic therapy (group 2) before the treatment and in dynamics (the $1^{\text {st }}$ and the $2^{\text {nd }}$ years), $\mathrm{Me}\left(\mathrm{Q}_{25} ; \mathrm{Q}_{75}\right)$

\begin{tabular}{|c|c|c|c|c|c|c|c|c|c|c|c|}
\hline \multirow[t]{2}{*}{ Domains } & \multicolumn{5}{|c|}{$1^{\text {st }}$ group, $n=71$} & \multicolumn{5}{|c|}{$2^{\text {nd }}$ group, $n=31$} & \multirow[t]{2}{*}{$\mathbf{U}^{* *}, \mathbf{p}$} \\
\hline & $\begin{array}{l}\text { Before } \\
\text { the SLIT }\end{array}$ & \begin{tabular}{|l} 
In one \\
year
\end{tabular} & $\begin{array}{l}W^{*}, \\
p \text { in compare } \\
\text { with before } \\
\text { the SLIT }\end{array}$ & $\begin{array}{l}\text { In two } \\
\text { years }\end{array}$ & $\begin{array}{l}\mathbf{W}^{*} \text {, } \\
\mathbf{p} \text { in compare } \\
\text { with before } \\
\text { the SLIT }\end{array}$ & \begin{tabular}{|l} 
Before \\
the sympto- \\
matic \\
treatment
\end{tabular} & $\begin{array}{l}\text { In one } \\
\text { year }\end{array}$ & $\begin{array}{l}W^{*}, \\
p \text { in compare } \\
\text { with before } \\
\text { the treatment }\end{array}$ & $\begin{array}{l}\text { In two } \\
\text { years }\end{array}$ & $\begin{array}{l}\mathbf{W}^{*}, \\
\mathbf{p} \text { in compare } \\
\text { with before } \\
\text { the treatment }\end{array}$ & \\
\hline Overall & $4(3 ; 4.5)$ & $2(2 ; 3)$ & $10, P<0.01$ & $1(1 ; 2)$ & $0, P<0.01$ & $4(3 ; 4.5)$ & $3(3 ; 4)$ & $21, P<0.01$ & $3(2 ; 3)$ & $21, P<0.01$ & $1956, P<0.05$ \\
\hline Activities & $4(3 ; 4)$ & $2(2,3)$ & $90, P<0.01$ & $1(1 ; 2)$ & $1, P<0.01$ & $3(3 ; 4)$ & $3(2 ; 3)$ & $88.5, P<0.01$ & $2(2 ; 2.5)$ & $28, P<0.01$ & $1737, P<0.05$ \\
\hline $\begin{array}{l}\text { Practical } \\
\text { problems }\end{array}$ & $4(3 ; 5)$ & $3(2,3)$ & $28, P<0.01$ & $1(1 ; 2)$ & $0, P<0.01$ & $4(4 ; 4)$ & $3(3 ; 3)$ & $24.5, \mathrm{P}<0.01$ & $3(2 ; 3)$ & $15, P<0.01$ & 1909.5, $P<0.05$ \\
\hline $\begin{array}{l}\text { Nose } \\
\text { symptoms }\end{array}$ & $4(3 ; 4)$ & $2(2 ; 3)$ & $15, P<0.01$ & $1(1 ; 2)$ & $0, P<0.01$ & $4(3 ; 4)$ & $3(3 ; 4)$ & $91, P<0.01$ & $3(2 ; 4)$ & $91, P<0.01$ & $2066, P<0.05$ \\
\hline $\begin{array}{l}\text { Eye } \\
\text { symptoms }\end{array}$ & $3(3 ; 4)$ & $2(2 ; 2)$ & $66, P<0.01$ & $1(1 ; 1.5)$ & $3, P<0.01$ & $3(2.5 ; 4)$ & $3(2 ; 3)$ & $153, P<0.05$ & $2(2 ; 3)$ & $111.5, P<0.01$ & $1926.5, P<0.05$ \\
\hline $\begin{array}{l}\text { Other } \\
\text { symptoms }\end{array}$ & $3(2 ; 3)$ & $2(2 ; 2)$ & $153, P<0.01$ & $1(1 ; 1)$ & $3, P<0.01$ & $3(2,3)$ & $2(2 ; 2.5)$ & $45, P<0.01$ & $2(1.5 ; 2.5)$ & $61, P<0.01$ & $1784.5, P<0.05$ \\
\hline
\end{tabular}

*W: Wilcoxon sum of the signed ranks; P: Probability value; **U: Mann-Whitney $U$ test results for group 1 after $2^{\text {nd }}$ year of treatment in compare with group 2. 
allergy was confirmed in 67 (88.1\%) individuals. Among them, two major molecules of Artemisia - Art v 1 and Art v 3 were detected in three patients. Out of 17 patients with positive SPT to Ambrosia, genuine allergy was confirmed in $15(88.2 \%)$ individuals. Meanwhile, co-sensitization to Ambrosia and Artemisia was observed in 21 persons. According to the results of molecular investigation, conduction of immunotherapy is recommended for 102 patients with detected major allergens of these weeds. However, SLIT was performed for only in 71 (69.6 \%) patients who constituted the first group of investigation. A control group of investigation involved 31 (30.4\%) individuals, who, for different reasons, and, first of all, due to financial problems, refused SLIT and were treated only symptomatically.

Using validated mini-questionnaire MiniRQLQ for patients in both groups, QOL estimation was performed before treatment and after the first and the second years of SLIT (the $1^{\text {st }}$ group) and symptomatic treatment (the $2^{\text {nd }}$ group). Data of analysis are given in Table 2.

The reliable decrease of all indices was established in patients of both groups following SLIT after the first and the second years of treatment $(P<0.01)$, except eye symptoms for the $2^{\text {nd }}$ group after the first year of treatment $(P<0.05)$. The reliable decrease of experienced allergy symptoms $(P<0.05)$ was also estimated in patients after the second year of SLIT in compare with the control group with symptomatic treatment.

\section{Discussion}

Currently, to specify QOL in patients with rhino-conjunctivitis, two basic questionnaires are used: RQLQ (rhino-conjunctivitis quality of life questionnaire) and Mini RQLQ (mini-rhino-conjunctivitis quality of life questionnaire). Usually, MiniRQLQ is used in clinical investigations, since it is more convenient as it contains fewer questions compared to RQLO, however, it is not less valid than the latter. In particular, in Indian investigation conducted in Mumbai, QOL of patients with atopic dermatitis (AD) was studied, using MiniRQLQ. The results showed that patients with $A D$ most often experienced symptoms, associated with rhinitis; Emotion-associated and Role limitation items were moderately revealed, while eye related, Physical functioning, Social functioning, Sleep-related \& Other Symptoms items were in the low range [6].

In our examination of patients with allergy to weed pollen based on MiniRQLQ questionnaire, we observed positive changes of QOL indices, indicating the efficacy of SLIT compared with symptomatic therapy. A reliable reduction of indices was observed in patients of the first group both after the first and the second year of SLIT $(P<0.01)$. The majority of patients in this group noted a significant alleviation of physical and mental condition, since reduction of clinical symptoms in pollination season allowed them to drive a car for a long time, join sport groups, carry out everyday duties actively etc. There was tendency to improvement of seasonal clinical symptoms only in four persons of the first group among polysensitized individuals. This fact is due to exacerbation of symptoms caused by the influence of other allergens. Besides, several patients in SLIT period had frequent respiratory viral diseases, and thus, decreased immune activity and temporary cessations of SLIT. Further, 68 patients agreed to continue SLIT, and three patients refused to proceed with the treatment due to personal causes.

In patients of the second group we also observed the reliable tendency to improvement of $\mathrm{QOL}$ indices after the symptomatic therapy. As expected, patients of the second group noted that clinical manifestations of allergy exacerbated from the end of July - the beginning of August (depending on weather conditions) and could only be controlled due to proper symptomatic therapy. In this group, 11 patients observed a slight reduction of clinical symptoms associating it with temporary change of living place (they moved to seashore); and five individuals noticed deterioration of their condition (clinical symptoms exacerbated and breathlessness appeared). It should be mentioned that eight patients of the second group decided to undergo SLIT in the future.

\section{Conclusions}

1. Among patients of Lviv region with pollen allergy, the most common is sensitization to Artemisia (62.3\%) and less to Ambrosia (13.9\%).

2. Component investigations enable to diagnose the presence of genuine allergy to weed pollen and thus to administer effective AIT. In our research, genuine allergy is confirmed in $88.1 \%$ (Artemisia) and $88.2 \%$ (Ambrosia) of patients.

3. Improvement of QOL indices after SLIT treatment indicated the high efficacy of this therapy method in patients with pollen allergy.

Conflicts of Interest: authors have no conflict of interest to declare. Конфмікт інтересів: віАсутній.

Information about authors:

Zubchenko S. O., MD, PhD, Assistant of the Department of Clinical Immunology and Allergology, Danylo Halytsky Lviv National Medical University, Ukraine.

Maruniak S. R., Medical Intern, specialty “Anesthesiology and Intensive Care" Shupyk National Medical Academy of Postgradual Education, Kyiv, Ukraine.

Відомості про авторів:

Зубченко С. О., канд. меА. наук, асистент каф. клінічної імунології та алергології, ^ьвівський національний медичний університет імені Аанила Галицького, Україна.

Маруняк С. Р., лікар-інтерн зі спеціальності "Анестезіологія та інтенсивна терапія", Національна медична академія післядипломної освіти імені П. ^. Шупика, м. Київ, Україна.

\section{Сведения об авторах:}

Зубченко С. А., канА. меА. наук, ассистент каф. клинической иммунологии и аммергологии, Аьвовский национальный медицинский университет имени Аанила Галицкого, Украина. Маруняк С. Р., врач-интерн по специальности «Анестезиология и интенсивная терапия", Национальная медицинская академия последипломного образования имени П. ^. Шупика, г. Киев, Украина. 
References

[1] Movérare, R., Larsson, H., Carlsson, R., \& Holmquist, I. (2011). Mugwort-Sensitized Individuals from North Europe, South Europe and North America Show Different IgE Reactivity Patterns. International Archives of Allergy and Immunology, 154(2), 164-172. doi: 10.1159/000320231.

[2] Léonard, R., Wopfner, N., Pabst, M., Stadlmann, J., Petersen, B. Duus, J., et al. (2010). A New Allergen from Ragweed (Ambrosia artemisiifolia) with Homology to Art v 1 from Mugwort. Journal of Biological Chemistry, 285(35), 27192-27200. doi: 10.1074/jbc.M110.127118.

[3] Niederberger, V. (2009). Allergen-specific Immunotherapy. Immunology Letters, 122(2), 131-133.

[4] Amaral, C. S., March, M. F., Sant'Anna, C. C. (2012). Quality of life in children and teenagers with atopic dermatitis. Brazilian Annals of Dermatology, 87(5), 717-23. doi: 10.1590/S0365-05962012000500008.

[5] Bousquet, J., Heinzerling, L., Bachert, C., Papadopoulos, N. G. Bousquet, P. J., Burney, P. G., et al. (2012). Position Paper EAACl Practical Guide to Skin Prick Tests in Allergy to Aeroallergens. Allergy, 67(1), 18-24. doi: 10.1111/j.1398-9995.2011.02728.x.

[6] Pherwani, A., Mankekar, G., Chavan, K., \& Bansode, G. (2008). The mini-rhino-conjunctivitis quality of life (qol) questionnaire (mrqlq) - self administered. Indian Journal of Otolaryngology and Head and Neck Surgery, 60(1), 20-4. doi: 10.1007/s12070-008-0008-y. 